\title{
The Shimmering Dam
}

\author{
JESSE SHIPWAY
}

UNIVERSITY OF TASMANIA

\section{$-1$}

When the whole culture is ankle deep in it, it will be exposed as a metaphor like a burnt stump, just out of the ground.

The black is the left over heat turned into colour or else it is the feeling of everything in the presence of something, wanting to be nothing, or leaning again towards it or against it as if it were something that mattered.

As if mattering is making something something, when it could just as easily be nothing or going that way; and if something is becoming something else, can there be any room for nothing and any room for time?

We should be old enough now to know that everything is getting closer to nothing at all. 
But from one of the middle shelves Grandfather took a much-tarnished, round silver dish, with a tray likewise of silver, and showed them both to the boy, lifting them separately and turning them about in his hands as he told the story he had so often told before.

Plate and basin, one could see, and as the little one heard once again, had not originally belonged together; but, Grandfather said, they had been in use together for a round hundred years, or since the time when the basin was made. The latter was very beautiful, of simple and elegant form, in the severe taste of the early nineteenth century. It rested, plain and solid, on a round base, and had once been gilt within, but the gilding had faded with time to a yellow shimmer. ${ }^{1}$

\section{$-3$}

All of this is private and then in a different conversation, or through a wall of air, we are sharing the world again and, with it, laws, customs and words.

Because, still, and again, everything is very nearly something else or going that way and there is always a silent stability in jokes and mirrors.

And you must be seeing with human eyes to notice difference; and the mingling edges in the falling heat.

Which, once again, is why pressure drops and air rushes up past eye level, toward subcommittees who defer and delay (differance) to safeguard what remains of the fractured state.

\section{$-4$}

There once lived a small boy. He had fair hair and a lively way. He lived with his mother and father on a little farm. The boy's childhood was happy and full. His parents loved him and he loved his parents. On his twelfth birthday, the boy's father presented him with a rowing boat. He helped the boy take the boat to the dam on the property. Together they launched the boat and the boy scrambled in. The father pushed the boat away from the shore, said goodbye to his son and turned to leave. He had walked only a few steps when he heard a cry. He turned to see that the boat had capsized. His son was swimming slowly toward the shore. He stood watching 
the boat as it sunk beneath the water. When the boy reached the edge of the dam, he tried to get out of the water, but his father wouldn't let him. He kept pushing the boy back down into the water. He pushed him down with both his arms. He had strong arms from all the farm work and the boy could not fight him. Again and again, the boy stood up and again and again his father pushed him down. After a while, the father turned and walked away. The boy was finally free of the water. He called after his father, begging him to wait. His father ignored the cries and walked away.

$-5$

If only it were true that love would last longer than a lifetime. If only it were possible to extend its modality beyond the horizon (crow's nest). The shimmering dam is a chronicle, remembered in song and captured in tapestries that hang in ancient homes.

shimmer $/ \int \operatorname{Im} ə / v$. \& n.・v.intr. shine with a tremulous or faint diffused light. $\bullet$. such a light. shimmeringly adv. Shimmery adj. [ORIGIN: Old English scymrian from Germanic: related to SHINE.]

$-7$

When I worked as a teacher's aide at Kingston High School, I had to attend an English class for Grade 9s that was held in the school library. All the time I was there I was on the defensive. I was trying to make books look macho. I was trying to look macho. I knew most of the kids thought I was a weirdo at best and a nerd at worst. Most of them probably didn't think about me too much at all. I used to pull out the Oxford Dictionary of Quotations and read from it in a sententious way. The teacher deferred to me. She said she felt intimidated by me because of my PhD. She was a good teacher. Anyway, I tried to talk to some of the boys about books and ideas and I read a poem out once that I wrote in class and I got a big cheer. The one kid who really seemed to have a thing for words-he was tall and good enough looking and he had mastered that lazy way of walking and talking that seemed to be in vogueasked me to suggest something for him to read. So I walked with him along the shelves and suggested Fahrenheit 451 and a couple of other books and he looked at them warily and lazily and rejected them all. So I asked him what he was interested 
in and he said war so we walked again along the shelves and I found a copy of Dam Busters and he took it and read it.

$$
-8
$$

The shimmering dam neutralises all ill-feeling and misdeeds. It is an antidote and a silver-bullet (pharmakon). When everything is said and done, it is nothing other than the possibility of change for the better.

Because things go badly we reach for substances or unhelpful habits, thoughts or places we like or fatty foods. The shimmering dam is the chance that this bad conscience will pass away, that this self-defeating, defeated and demoralising behaviour is just a leaf on a tree that changes colour as the air cools and falls later to the downtrodden earth.

$-9$

more and more lately as not even minding the slippages yet the aches and sad softenings I settle into my other years I notice how many of what I once thought were evidences of repression sexual or otherwise now seem in other people anyway to be varieties of dignity withholding tact and sometimes even in myself certain patiences I would have once called lassitude indifference now seem possible to be if not the rewards then at least the unsuspected undreamed of conclusions to many even then preposterous self evolved disciplines rigors almost mortifications I inflicted on myself in my starting out days improvement days, days when the idea alone of psychic peace of intellectual of emotional quiet the merest hint would have meant inconceivable capitulation. ${ }^{2}$

$-10$

Could it be that everything is as it appears? If this were so, the shimmering dam would play no role in our lives or in our literature. The SD is a kind of deception, a basic lie; predicated on the idea that what we want is always unavailable, that when we say one thing we always mean something else and everything is deflected or on the ricochet, off the cushion, seldom in the corner pocket. 
Stage One (the Middle Gordon scheme) aims at producing 240,000 kW generator capacity from a 600 foot head of water. The storage will be created by dams across the Serpentine and the Gordon very close to their junction; a third dam is also required at Scotts Peak across the Huon River headwaters. Construction of these three dams will result in the creation of Australia's largest artificial storage with a useful capacity of $10 \mathrm{~m}$ acre feet. ${ }^{3}$

\section{$-12$}

In the act of beginning, you started to say the air from your mouth that sounded like words. But before that there was the offer of analysis without the imprimatur of anyone, really just two people going at it, against the clock with books there unread and understood even less, or else in a way distinct from authorial intent, and across the road, renovations, wood the colour of straw and a plastic floor.

$$
-13
$$

'No,' Phyllis says darkly. 'You know, Frank, Joe's a manic-depressive.'

'No, I didn't know that.' I hug my clipboard tighter. (I'm beginning to cook like a cabbage in my windbreaker.) I mean, though, to hold my ground. Manic-depressives, convicted felons, men and women with garish tattoos over every inch of their skin: all are entitled to a hook to hang their hats on if they've got the scratch. ${ }^{4}$

\section{$-14$}

The shimmering dam is a substitute for memory because it privileges action over reflection. To work as an agent of the SD you have to break out of the present and drive hard through the defence to the end-zone up ahead. This offense is like a wildcat strike, a jailbreak or the detonation of an improvised explosive device. It's futile in the long run because the SD sends out trackers who will pick out your scent from the swale to the rabbit proof fence. The agents of the SD (regulators) will head you off at the pass or on top of the mesa and shoot you down in cold blood (West Texas Crude).

$$
-15
$$

At first sight, the statement appears as an ultimate, undecomposable element that can be isolated and introduced into a set of relations with other similar elements. A 
point without surface, but a point that can be located in planes of division and in specific forms of groupings. A seed that appears on the surface of a tissue of which it is the constituent element. The atom of discourse. ${ }^{5}$

$-16$

Many statements are stamped with the seal of the shimmering dam (lemon juice/domestic oven/untimely death). These collections of words yield a subterranean glow. They can be mined open-cut, but the trader who traffics in them does so at her own peril. She must manage the risk that the statements will flee to the bedrock from whence they came. Ownership of these statements is always temporary and defies probabilistic reasoning, judicial precedent and even deep-ecology. When all is said and done, you would be better off dropping your rent money through the coin slots of diabolical casino machines.

$-17$

Of course from Sartre's point of view, the theory of repetition itself could be another piece of bad faith, an especially suitable alibi. Indeed this misgiving might make us wonder, as we look at the case of Little Hans, what fear, or so-called self-knowledge, would be like if we did not believe in repetition? If there was no such thing as repetition, what would we be using fear to explain? If there was no repetition-if we stopped believing in such a thing-what self would we have knowledge of? ${ }^{6}$

\section{$-18$}

And there are no eyes left, but hominid eyes, the self-same eyes that saw Paris burn and Agamemnon take to the Hittites with his flaming sword.

Which is why the newest is the oldest and the oldest the youngest on the chart of history as just one life, which it is, as a tree or a bulb or a map or instructions for flat pack furniture or a policy document.

$-19$

Echo was a nymph deprived of speech by Hera in order to stop her chatter. She was able only to repeat what was said by others. Narcissus rejected her and she wasted away with grief until only her voice remained. 
It is the same with emotions because they take displaced objects and infuse them with energy. The dam is there for questions and the first one must always be: How can we live without money except through the kindness of strangers? And why, if you're good at something, must you go without? Is it because nobody wants what you make even though it is good? The answer must be that it is not good enough.

\section{$-21$}

She sat in a green imitation leather chair with her arms resting on its tubed chrome arms and her feet flat on the floor in their slippers. She looked awful. Her dark hair was combed back off her face in a way she would never have combed it. She always parted it in the middle and tied it at the back of her neck. Her skin looked blotchy. She was not a small person but she looked physically small sitting there. Not looking at him, she lifted her arm, her fingers dipping toward him, a bored, humorous, gesture, one that made his heart leap; and he took the outraised hand in both his hands thinking It's her, it's still her, no matter what she does, and only then noticing in front of his eyes the taped bandage around her wrist. ${ }^{7}$

\section{$-22$}

I've been off work now for almost four weeks. I don't ever want to go back. I want to be free to live my life as I want to lead it. Let someone else do the government's bidding. I will not be forced to work.

$-23$

A new generation in the 1960s woke up one day to look out the window, and saw their own cities as absurd. They were alert to the excess that surrounded them, and inclined to action, at least to finding a way of proving themselves, charting a different path, one out of the metaphysical slum in which they felt they had been born.

Once more they took to politics in search of a saving belief-this time a brand of anarcho-pacificism. True to the coercive script, blind to the trap, they were, like Marlow, seduced by the intoxicating beat from the jungle, but plotted their course through music and drugs. Demonstrating against their own era's war-Vietnam- 
made their practical politics. This was journey by negation, the repressive constraints of a run-down civilization to be stripped off, allowing regression into the child idyll of a love-and-play utopia set in perpetual springtime. ${ }^{8}$

\section{$-24$}

Objects enclose space even when they are solid, the space turns in, enfolds matter (Leibniz) and it's all moving when you put your eye right to it and touch it with your pupil after your lashes.

$$
-25
$$

Each type of government enacts laws that are in its own interest, a democracy democratic laws, a tyranny tyrannical ones and so on; and in enacting these laws they make it quite plain that what is 'right' for their subjects is what is in the interest of themselves, the rulers, and if anyone deviates from that he is punished as a lawbreaker and 'wrongdoer'. That is what I mean when I say 'right' is the same thing in all states, namely the interest of the established government; and government is the strongest element in each state, and so if I argue correctly we see that 'right' is always the same, the interest of the stronger part. ${ }^{9}$

$$
-26
$$

And other objects are just as good for it too, and every 'thing' that is solid should be grouped in this way for the space it takes up and not for its function because function is old and beside the point.

$-27$

It was my tutor who dissuaded me from patronizing Green or Blue at the races, or Light or Heavy in the ring; and encouraged me not to be afraid of work, to be sparing in my wants, attend to my own needs, mind my own business, and never listen to gossip. ${ }^{10}$

$-28$

We go to it as a mirror and a mirage; language itself, or communication or the generation of meaning, like electricity, that could tell us about ourselves, wire in the 
blood, intervals and tab stops, but its tain is crumpled silver because the rain has lowered its colours.

$-29$

We know now that a text is not a line of words releasing a single 'theological' meaning (the 'message' of the Author-God) but a multi-dimensional space in which a variety of writings, none of them original, blend and clash. The text is a tissue of quotations drawn from innumerable centres of culture. 11

$-30$

No one goes to it.

The road passes it.

Nobody thinks of it.

Again, like the sun seeking darkness, like a snake leaping out of its skin.

$-31$

He who cannot find a game worth playing is apt to fall prey to accidie, defined by the Fathers of the Church as one of the Deadly Sins, but now regarded as a symptom of sickness. Accidie is a paralysis of the will, a failure of the appetite, a condition of generalized boredom, total disenchantment-'God, oh God, how weary, stale, flat and unprofitable seem to me all the uses of this world'.12

$-32$

The particularity of substances is noted again and again as items or events in inventories and on calendars, or else as children who are known to the whole street and then, to neutralise history, people hold on for longer to things and thoughts and other beings.

$-33$

After the glib disavowal of affect that is a displacement like the ballast of optimism, a blast of goodwill or at least the idea that things could possibly be that way, there is still progress and its feeding tubes. 
When I started collecting books, I was a pretty manic. I gathered items that I thought were of value but turned out to be junk. It's amazing how you keep coming across the same books in op shops and antique shops and garage sales.

$$
-35
$$

Really it is outside and away from all of us and it means little more than its body or its extension.

It is a solid commonwealth, because it has parts, private and given, a charitable institution if not a gift that is vouchsafed or aground like water is aground or washed away downstream.

\section{$-36$}

The anarchic character of international relations in which sovereign states find themselves suggests a comparison with the 'state of nature', familiar from social contract theory, in which pre-social individuals are supposed to have found themselves. The social contract teaches them that the only way out of their wretched condition of unremitting insecurity is to organize themselves as citizens of a state. ${ }^{13}$

\section{$-37$}

And finally they drown together in an iridescent pool of intentions and light; cool enough as willing or as grist or kale.

The line of time is like a ribbon or the line of a kite; letting out more gives you less in the end.

Because even the will to live has cooled and the will to sustain one's self or to endure has cooled.

Everything has cooled and is starting to freeze. 
Jesse Shipway is a research fellow in the School of Sociology and Social Work at the University of Tasmania. He is working right now on a poetry manuscript entitled The Travel Effect as well as a series of collages on inequality, the fear of death and other topics. He edits Anastomoo (www.anastomoo.com) and lives with his family in Hobart.

-NOTES

1 Thomas Mann, The Magic Mountain, Penguin, Harmondsworth, 1960, p. 22.

2 C.K. Williams, 'Repression', in Margaret Ferguson, Mary Jo Salter, Jon Stallworthy (eds), The Norton Anthology of Poetry, fourth edn, W.W. Norton, New York, 1998, p. 1762.

3 Tasmanian Year Book, Hobart, 1970, p. 388.

4 Richard Ford, Independence Day, Harvill, London, 1996, p. 78.

5 Michel Foucault, The Archaeology of Knowledge, Tavistock Publications, London, 1985, p. 80.

6 Adam Phillips, Terrors and Experts, Faber and Faber, London, 1995, p. 57.

7 E.L. Doctorow, The Book of Daniel, Macmillan, London, 1972, p. 8.

8 John Carroll, Terror: A Meditation on the Meaning of September 11, Scribe, Melbourne, 2002, p. 31.

9 Thrasymachus in Plato, The Republic, Penguin, London, 2003, p. 19.

10 Marcus Aurelius, Meditations, Penguin, London, 1964, p. 35.

11 Roland Barthes, 'The Death of the Author', in David Lodge (ed.), Modern Criticism and Theory: A

Reader, Longman, London \& New York, 1988, p. 170.

12 Robert S. De Ropp, The Master Game, Picador, London, 1969, p. 11.

13 Jurgen Habermas, The Divided West, Polity, Cambridge, 2006, p. 129. 